\title{
Pensatempos, de Mia Couto: na outra margem da ficção, o papel do escritor diante da realidade
}

\author{
Susanna Ramos Ventura \\ Universidade de São Paulo
}

ia Couto parece vivenciar situação similar à de muitos outros intelectuais africanos a partir do século XX - constantemente instados a intervir nas várias esferas de poder e saber de seus países, que ajudam efetivamente a construir; chamados e convidados a discursar e opinar sobre os mais variados assuntos. Nos últimos anos, intensifica-se no discurso do autor moçambicano o clamor pela produção do que chama de "pensamento próprio". Numa polêmica conferência, proferida em Maputo no início de 2005 e intitulada "Os sete sapatos sujos", o autor detém-se sobre este ponto:

Se não mudarmos de atitude não conquistaremos uma condição melhor. Poderemos ter mais técnicos, mais hospitais, mais escolas, mas não seremos construtores de futuro. Falo de uma nova atitude, mas a palavra deve ser pronunciada no plural, pois ela compõe um conjunto vasto de posturas, crenças, conceitos e preconceitos. Há muito que venho defendendo que o maior factor de atraso em Moçambique não se localiza na economia, mas na incapacidade de gerarmos um pensamento produtivo, ousado e inovador. Um pensamento que não resulte da repetição de lugares comuns, de fórmulas e de receitas já pensadas pelos outros. Às vezes me pergunto: de onde vem a dificuldade em nos pensarmos como sujeitos da História? Vem sobretudo de termos legado sempre aos outros o desenho da nossa própria identidade. Primeiro, os africanos foram negados. O seu território era a ausência, o seu tempo estava fora da História. Depois, os africanos foram estudados como um caso clínico. Agora, são ajudados a sobreviver no quintal da História. ${ }^{1}$

\footnotetext{
1 "Os sete sapatos sujos - oração de sapiência", de Mia Couto, está disponível em <http:// www.comunistas.info/mia.htm>. Acessado em 3 de outubro de 2005.
} 
Pensatempos - textos de opinião, publicado pela Editorial Caminho em 2005, permite a observação de um vasto conjunto de dezoito intervenções de Mia Couto que, reunidas em formato livro, mostram as várias faces de um autor que parece se dividir pelos papéis de ecologista, biólogo, escritor, moçambicano e africano. Dos textos reunidos no livro merecem especial atenção os ensaios "A fronteira da cultura", "Uma palavra de conselho e um conselho sem palavras", "Que África escreve o escritor africano?” e "Por um mundo escutador".

"A fronteira da cultura" foi uma palestra pronunciada por Mia Couto na Associação Moçambicana de Economistas, em agosto de 2003. Nela, o escritor parte de sua experiência como docente da Universidade Eduardo Mondlane, em Maputo, e questiona a "pobreza" de Moçambique, preferindo considerar que o país "foi empobrecido". Lança a hipótese de que a perpetuação e o agravamento desse estado podem advir da falta de idéias próprias, da erosão da criatividade e da ausência de debate produtivo. Novamente, Mia Couto aponta para a necessidade da fundação de valores próprios, e para o (re)conhecimento do país e de sua diversidade por seus cidadãos, em especial os jovens com acesso à educação, que podem transformar-se de consumidores em produtores de pensamento. No entanto, suas reflexões não se restringem apenas a eles, uma vez que o afastamento da realidade local é tributado a todo o estrato social para o qual fala o escritor: "A verdade é que ainda mantemos um grande desconhecimento das dinâmicas actuais, dos mecanismos vivos e funcionais que esse tal povo inventa para sobreviver. Sabemos pouco sobre assuntos de urgente e primordial importância" (COUTO, 2005: 17-18). Como ocorre na maioria de suas reflexões sobre Moçambique na contemporaneidade, Mia Couto estende várias de suas considerações ao continente africano e trata das dinâmicas existentes entre Moçambique e África (particularizando alguns de seus países) e das rotulações que país e continente, vistos como um bloco, costumam partilhar no cenário internacional.

"Uma palavra de conselho e um conselho sem palavras" - um dos ensaios mais iluminadores para os estudiosos e leitores da obra ficcional de Mia Couto - surgiu como um texto elaborado para "crianças lusófonas", participantes de um programa denominado "Ciência Viva”, em julho de 2004. Talvez pela circunstância de se dirigir a crianças de vários países que falam o português 
e às quais provavelmente foi apresentado como escritor, Mia Couto tenha se voltado para os territórios da criação literária e reafirmado pontos que seus leitores adultos costumam encontrar tanto na obra, como nas interpretações dela proferidas pelo autor. A afirmação da importância da poesia ("um outro modo de pensar que está para além da lógica que a escola e o mundo moderno nos ensinam" - COUTO, 2005: 45); a ligação - que passa pela "escuta" - com o universo encontrado na zona rural ("Este mundo rural, distante dos compêndios científicos, não tem menos sabedoria que o mundo urbano onde vivemos. Estar disponível para escutar nessa linha de fronteira [...]" - COUTO, 2005: 46); sua maneira de compor uma obra literária (“O meu segredo [...] é deixar-me maravilhar por histórias que escuto" - COUTO, 2005: 46); e, finalmente, a importância conferida às histórias ouvidas, consideradas semente da criação poética, remetem ao conteúdo do "Texto de abertura" a Vozes anoitecidas, de 1986. Após o desvendamento de seu universo ficcional, Mia Couto parte para situar Moçambique: "minha terra”, "um país pobre”, "onde nasci e vivo" (COUTO, 2005: 48), habitado por pessoas com vários modos de ver o mundo e com sua sabedoria própria, advindos ou não da escrita. A bela finalização do ensaio une os universos da ciência e da poesia, atribuindo ao conhecimento o poder de nos fazer "mais companheiros das criaturas vivas e não vivas com quem partilhamos este universo" (COUTO, 2005: 49).

O ensaio “Que África escreve o escritor africano?” foi originalmente um discurso, pronunciado em agradecimento a um prêmio literário destinado aos melhores romances escritos na África em 2002, e toca em vários pontos da atuação de Mia Couto como escritor e como cidadão. $\mathrm{O}$ primeiro tema levantado, o da luta do escritor por um mundo mais humano e democratizado, vem acompanhado da afirmação da responsabilidade do intelectual diante da defesa da democracia e do respeito aos direitos humanos. A colocação do escritor como criatura de fronteira parece espelhar, para os leitores da obra ficcional do autor, toda uma galeria de personagens que normalmente realizam a ligação entre os mundos da escrita e da oralidade - como Kindzu, de Terra sonâmbula, o tradutor de Tizangara, de O último voo do flamingo, e Mariano, de Um rio chamado tempo, uma casa chamada terra. Mia Couto arrola para os escritores o papel da criação de um pensamento próprio capaz de avaliar de dentro o país, seu tempo e os conceitos que lhes foram impostos 
(como o de "africanidade"). A mestiçagem é outro conceito que vem sendo trabalhado por Couto, tanto na literatura quanto nas intervenções sociais que realiza. Na literatura, por exemplo, personagens como Surendra Vala (Terra sonâmbula) se consideram homens "sem raça". Nesse ensaio, como em vários outros do livro, Mia Couto fala sobre a importância da aceitação da diversidade e da superação de conceitos ultrapassados, como o de pureza legado colonial que, relido na contemporaneidade, dá margem a novas e equivocadas buscas essencialistas, como a que pretende encontrar uma "essência" africana. Outra tensão aparece com freqüência na ficção do autor: a que coloca em lados opostos, e não conciliáveis, "tradição" e "modernidade".

Mia Couto coloca-se, aqui, simplesmente como "escritor", acima de reduções que são impostas aos escritores africanos, a quem se pedem provas de "africanidade" impensáveis para autores dos outros continentes. No entanto, assume-se como produtor de pensamento e fala em nome dos escritores moçambicanos, que cumprem o compromisso ético de ajudar a sonhar um país melhor. Mia Couto equilibra, assim, a posição de escritor que recusa rótulos redutores com a de escritor que, africano e moçambicano, toma para si as dificuldades que tais "facetas identitárias" carregam consigo.

Finalmente, em "Por um mundo escutador", Mia Couto reforça, a partir do título, os laços que o ligam ao universo oral, ousando sonhar com um "mundo que escuta as vozes diversas, em que todos são, em simultâneo, centro e periferia" (COUTO, 2005: 155), uma resposta inovadora à globalização desumanizadora que, via de regra, denuncia. Nesse pequeno ensaio, escrito para um livro organizado pelo sociólogo Boaventura de Souza Santos, Mia Couto volta a questionar a imagem que os países pobres fazem de si mesmos, deformada por padrões historicamente legados juntamente com juízos de valor hoje ultrapassados. Além disso, traz novamente o questionamento das "identidades", necessariamente múltiplas e mestiças em países que, como Moçambique, foram colonizados no passado e fazem parte no presente do elenco de países mais pobres do mundo. Segundo Mia Couto, são esses países os que precisam olhar para si mesmos de maneira corajosa, saindo da posição de eternas vítimas para assumir a responsabilidade da construção de sociedades capazes de contemplar e acomodar sua diversidade humana e cultural.

Pensatempos - textos de opinião dá ao leitor a oportunidade de se aproximar da atuação social do escritor Mia Couto, bem como permite um conheci- 
mento mais aproximado da realidade de Moçambique na contemporaneidade. Para a grande maioria de leitores, que chega aos ensaios depois de conhecer parte da obra ficcional de Mia Couto, a leitura se transforma numa estrada de caminhos que se bifurcam e aprofundam, uma vez que os diálogos e relações entre os ensaios e a obra ficcional constituem-se num campo rico de reflexões e questionamentos, em que se ampliam e alimentam as possibilidades de interpretação.

\section{Referência Bibliográfica}

COUTO, Mia. Pensatempos - textos de opinião. Lisboa: Caminho, 2005. 157 p. 
